\title{
Kualitas Fisik, Mikrobiologi dan Organoleptik Sosis Ayam Komersil yang Beredar di Tempat Berbeda di Bogor
}

\author{
Physical Quality, Microbiological and Organoleptic Chicken Sausage at Different Place in Bogor
}

M. Yusuf, R. R. S. Wihansah, M. Arifin, A. Y. Oktaviana, Rifkhan, J. K. Negara, A. K. Sio

Mahasiswa Sekolah Pascasarjana, Departemen Ilmu Produksi dan Teknologi Peternakan

Fakultas Peternakan, Institut Pertanian Bogor

Email : thtseru@gmail.com

\begin{abstract}
This study aimed to evaluate the quality of physical, microbiological and organoleptic chicken sausage around on campus IPB, Bogor to evaluate its feasibility. Chicken sausage samples obtained from two groups of different markets, namely supermarket and traditional market. The design of the treatment of this study consisted of two treatment that sausage that comes from the traditional markets (stored at room temperature) and sausage that comes from the supermarket (stored at cold temperatures) and each market was taken a sample of three replications. The physical quality was observed $\mathrm{pH}$ and $\mathrm{a}_{\mathrm{w}}$, while the microbiological quality was observed quantitative testing total microbial colonies (PCA), E. coli, Salmonella sp, Staphylococcus aureus, according to the BSN (2008) and FDA method (1998). Organoleptic quality chicken sausage test was using hedonic test. The results showed that the chicken sausages in the market around the campus of IPB was still feasible for consumption due to microbial contamination was still low compared with SNI and organoleptic sausage was still accepted by the panelists.
\end{abstract}

Keywords : chicken sausage, microbiological, organoleptic, quality of physical

\section{PENDAHULUAN}

Kesibukan dan tuntutan hidup masyarakat saat ini mengakibatkan bergesernya pola konsumsi masyarakat dari mengkonsumsi daging segar menjadi daging olahan cepat saji (ready to cook). Makanan cepat saji sekarang ini sudah menjadi gaya hidup, karena selain harganya terjangkau, makanan cepat saji mudah diolah, praktis dan tahan lama, serta rasanya pun enak. Salah satu makanan cepat saji yang sering dikonsumsi yaitu sosis. Sosis merupakan salah satu diversifikasi produk pangan asal hewan yang merupakan campuran dari daging halus (tidak kurang dari 75\%) dengan tepung, bumbu-bumbu serta bahan tambahan makanan lain yang diizinkan yang dimasukan ke dalam selongsong sosis serta mengacu pada syarat mutu sosis Standar Nasional Indonesia 01-3020 (BSN 1995). Dalam proses pembuatannya, bahan baku sosis terdiri dari dua yaitu bahan utama dan bahan tambahan. Bahan utama untuk proses pembuatan sosis terdiri atas daging, es, minyak, garam dan lemak. Sedangkan bahan tambahannya yaitu bumbubumbu, bahan pengikat, bahan pengisi, bahan penyedap dan bahan tambahan lainya yang diizinkan. Menurut Kramlich (1973) definisi dari sosis adalah merupakan salah satu makanan yang terbuat dari cacahan daging yang dibungkus dalam sebuah casing menjadi bentuk silindris.

Sosis merupakan produk olahan daging yang bersifat mudah rusak (perishable) karena kandungan nutrisi di dalamnya dapat dimanfaatkan oleh mikroorganisme untuk hidup. Pertumbuhan mikroba pada bahan pangan yang tidak diinginkan dapat dijumpai dalam bentuk kerusakan pangan dan penyakit yang timbul akibat mengkonsumsi produk pangan yang terkontaminasi mikroba patogen (foodborne disease). Penyakit akibat makanan (foodborne disease) dan diare karena cemaran air membunuh sekitar 2 juta orang pertahun, termasuk diantaranya anak-anak (Kemenkes RI 2015). Jumlah kasus keracunan makanan di Indonesia tahun 2015 sebesar 814 kasus (BPOM 2015). Terkait dengan adanya ancaman foodborne disease tersebut maka hendaknya sosis yang beredar di masyarakat sudah sesuai dengan standar yang berlaku.

Penyimpanan dan preservasi merupakan kunci penting yang harus diperhatikan, terlebih lagi rantai pasar produk sosis dari produsen sampai ke tangan konsumen cukup panjang dan beragam. Jika metode penyimpanan dan preservasi sosis tidak dilakukan dengan baik maka akan mempengaruhi kualitas fisik, mikrobiologi serta tingkat penerimaan masyarakat. Berdasarkan hal di atas maka perlu adanya penelitian untuk mengevaluasi kualitas fisik, mikrobiologis, dan organoleptik dari sosis yang ada di masyarakat untuk melihat kelayakannya, dengan studi kasus pada sosis ayam yang beredar di sekitar kampus IPB, Darmaga, Bogor. 


\section{MATERI DAN METODE}

\section{Pengambilan Sampel Sosis}

Penelitian ini menggunakan sample sosis ayam yang diambil secara sampling dari dua kelompok pasar yang berbeda, sebagai perlakuannya yaitu perlakuan A pasar tradisional (sosis yang disimpan dengan suhu ruang) dan perlakuan B pasar swalayan (sosis yang disimpan pada suhu dingin). Pasar yang digunakan untuk pengambilan sampel ditentukan secara sengaja (purposive), hal ini dimaksudkan karena pertimbangan di lokasi tersebut merupakan pusat jual beli sosis ayam dengan konsumen akhir sebagai pembelinya. Sampel sosis yang didapat dari pasar swalayan ditempatkan pada wadah plastik kemudian disimpan pada cooling box agar tetap tersimpan pada suhu dingin, sedangkan sampel sosis yang didapat dari pasar tradisional dibawa langsung menggunakan wadah plastic dengan suhu ruang. Selanjutnya sampel yang didapat langsung dibawa ke laboratorium untuk dianalisis kualitas fisik, mikrobiologi, dan uji organoleptiknya.

\section{Kualitas Fisik}

Kualitas fisik pada sosis yang diukur meliputi $\mathrm{pH}$ dan $\mathrm{a}_{\mathrm{w}}$ dimana $\mathrm{pH}$ sosis diukur dengan menggunakan $\mathrm{pH}$ meter daging HI 99163 sedangkan $\mathrm{a}_{\mathrm{w}}$ sosis dilakukan dengan cara sampel sosis sebanyak 2-3 gram yang sudah dihancurkan sampai homogen kemudian diukur dengan $\mathrm{a}_{\mathrm{w}}$ meter (Novasina ms-1).

\section{Total Plate Count}

\section{Kualitas Mikrobiologi}

TPC dilakukan dengan metode pour plate dimana sampel sosis yang sudah dihancurkan sebanyak 25 gram dimasukkan ke dalam $225 \mathrm{ml}$ media Buffer Peptone Water (BPW) $0,1 \%$ steril sehingga didapat pengenceran $10^{-1}$ (P1). Sebanyak $1 \mathrm{ml}$ suspensi dari P1 dipindahkan dengan pipet steril ke dalam $9 \mathrm{ml}$ media BPW 0,1\% steril untuk mendapatkan pengenceran $10^{-2}(\mathrm{P} 2)$, dengan cara yang sama dilakukan pengenceran sampai dengan pengenceran $10^{-5}$ (P5).

Selanjutnya dari masing-masing pengenceran 10 ${ }^{3}, 10^{-4}$ dan $10^{-5}$ diambil $1 \mathrm{ml}$ untuk dimasukkan ke dalam cawan petri steril dengan system duplo, kemudian dituang sebanyak 10-15 ml media cair plate count agar (Oxoid CM 0325) steril dan dihomogenkan dengan cara menggeserkan cawan horizontal atau membentuk angka delapan dan dibiarkan hingga memadat. Tahap selanjutnya diinkubasikan pada suhu $37^{\circ} \mathrm{C}$ dengan posisi cawan terbalik selama 24-48 jam. Penghitungan koloni dilakukan dengan menggunakan colony counter berdasarkan ketentuan Standar Plate Count (SPC). Penetapan jumlah koloni dilakukan dengan menggunakan metode Bacteriological Analitical Manual (BAM) FDA (1998).

\section{Analisis E. Coli}

Analisis E. coli dilakukan dengan metode pour plate dimana sampel sosis yang sudah dihancurkan sebanyak 25 gram dimasukkan ke dalam $225 \mathrm{ml}$ media Buffer Peptone Water (BPW) 0,1\% steril sehingga didapat pengenceran $10^{-1}$ (P1), Sebanyak $1 \mathrm{ml}$ suspensi dari P1 dipindahkan dengan pipet steril ke dalam $9 \mathrm{ml}$ media BPW 0,1\% steril untuk mendapatkan pengenceran $10^{-2}(\mathrm{P} 2)$, dengan cara yang sama dilakukan pengenceran sampai dengan pengenceran $10^{-3}$ (P3).

Selanjutnya dari masing-masing pengenceran $10^{-}$ ${ }^{1}, 10^{-2}$ dan $10^{-3}$ diambil $1 \mathrm{ml}$ untuk dimasukkan ke dalam cawan petri steril dengan system duplo, kemudian dituang media cair selektif Eosin Methylene Blue Agar (EMBA, Himedia M022-500G) dan diinkubasikan pada suhu $37^{\circ} \mathrm{C}$ dengan posisi terbalik selama 24 jam. Koloni yang tampak hijau metalik dalam media EMBA dihitung sebagai koloni E. Coli.

\section{Analisis S. aureus}

Analisis $S$. aureus dilakukan dengan metode pour plate dimana sampel sosis yang sudah dihancurkan sebanyak 25 gram dimasukkan ke dalam $225 \mathrm{ml}$ media Buffer Peptone Water (BPW) 0,1\% steril sehingga didapat pengenceran $10^{-1}(\mathrm{P} 1)$, Sebanyak $1 \mathrm{ml}$ suspensi dari P1 dipindahkan dengan pipet steril ke dalam $9 \mathrm{ml}$ media BPW $0,1 \%$ steril untuk mendapatkan pengenceran $10^{-2}(\mathrm{P} 2)$, dengan cara yang sama dilakukan pengenceran sampai dengan pengenceran $10^{-3}$ (P3).

Selanjutnya dari masing-masing pengenceran $10^{-}$ ${ }^{1}, 10^{-2}$ dan $10^{-3}$ diambil $1 \mathrm{ml}$ untuk dimasukkan ke dalam cawan petri steril dengan system duplo, yang sebelumnya sudah dimasukkan media BPA (Oxoid CM0275) + tellurit + egg yolk 5\%, kemudian suspensi disebar di atas permukaan media dengan metode spread plate dengan menggunakan batang gelas bengkok (hockey stick) dan dibiarkan selama kurang lebih 30 menit pada suhu ruang. Selanjutnya diinkubasi pada suhu $37^{\circ} \mathrm{C}$ dengan posisi cawan terbalik selama 24 jam. Koloni $S$. aureus pada BPA mempunyai ciri : bundar, licin halus, cembung, diameter 2-3 mm, wama abu-abu sampai kehitaman, tepi koloni putih dan dikelilingi daerah yang terang (SNI 01-2897-2008).

\section{Analisis Salmonella sp}

Analisis Salmonella sp. dilakukan dengan metode pour plate dimana sampel sosis yang sudah dihancurkan sebanyak 25 gram dimasukkan ke dalam $225 \mathrm{ml}$ media Buffer Peptone Water (BPW) 0,1\% steril sehingga didapat pengenceran $10^{-1}(\mathrm{P} 1)$, Sebanyak $1 \mathrm{ml}$ suspensi dari P1 dipindahkan dengan pipet steril ke dalam $9 \mathrm{ml}$ media BPW $0,1 \%$ steril untuk mendapatkan pengenceran $10^{-2}(\mathrm{P} 2)$, dengan cara yang sama dilakukan pengenceran sampai dengan pengenceran $10^{-3}(\mathrm{P} 3)$.

Selanjutnya dari masing-masing pengenceran $10^{-}$ ${ }^{1}, 10^{-2}$ dan $10^{-3}$ diambil $1 \mathrm{ml}$ untuk dimasukkan ke dalam cawan petri steril dengan system duplo, kemudian dituang media cair selektif Xilose Lysine Desoxycholate (XLDA) dan diinkubasikan pada suhu $37^{\circ} \mathrm{C}$ dengan posisi cawan terbalik selama 24 jam. Koloni yang tampak merah dengan tengah kehitaman pada media XLD dihitung sebagai koloni Salmonella sp.

\section{Uji Organoleptik}

Pengujian organoleptic dilakukan di laboratorium organoleptik IPTP IPB dengan menggunakan 20 orang panelis tidak terlatih berdasarkan skala hedonik meliputi warna, rasa, aroma, tekstur dan total penerimaan. Skala penilaian uji hedonik menggunakan 5 Skala dengan skala numeriknya yaitu sangat tidak suka $=1$, tidak suka=2, netral $=3$, suka $=4$ dan sangat suka $=5$ (Meilgaard et al. 1999). 
Prosedur pengujian organoleptik diantaranya sampel sosis diletakkan di atas piring yang telah diberi kode 3 digit yang berbeda berdasarkan asal sosis, alat tulis, kuisioner, bubuk kopi dan satu gelas air disiapkan, panelis diberi arahan atau penjelasan singkat mengenai cara pengujian organoleptik, selanjutnya panelis memberikan penilaian terhadap sampel.

\section{Rancangan Percobaan}

Rancangan perlakuan yang digunakan adalah 1 faktor yaitu suhu penyimpanan sosis yaitu suhu ruang (sosis dari pasar tradisional) dan suhu dingin (sosis dari pasar swalayan). Rancangan lingkungan yang digunakan adalah Rancangan Acak Lengkap (RAL) Data kualitas fisik dan mikrobiologi dianalisa dengan menggunakan uji t-student, (Mattjik dan Sumertajaya, 2013). Data sifat organoleptik (warna, rasa, bau, tekstur dan total penerimaan) sosis dianalisa menggunkan Uji Kruskal-Wallis yaitu uji statistika non parametrik (Siegel, 1992). Data yang tidak memenuhi kaidah statistik diuraikan secara deskriptif.

\section{HASIL DAN PEMBAHASAN}

\section{Kualitas Fisik}

Hasil uji statistic menunjukkan bahwa rata-rata $\mathrm{pH}$ dan $\mathrm{a}_{\mathrm{w}}$ baik pada sosis yang berasal dari pasar tradisonal maupun swalayan tidak berbeda nyata $(\mathrm{P}>0,05)$. Hasil pengamatan terhadap kualitas fisik sosis berupa $\mathrm{pH}$ yang diperoleh sesuai dengan penelitian yang dilakukan oleh Irianto et al. (1994) yang menyatakan bahwa nilai $\mathrm{pH}$ sosis ayam yang beredar di pasaran berkisar antara 5,12-7,20. Sedangkan untuk nilai a yang didapat dari kedua kelompok sosis ini masih memungkinkan untuk pertumbuhan bakteri (Jay 2005; Muttaqien et al. 2013). Nilai a dapat dijadikan indikator untuk memprediksi kestabilan dan keamanan pangan karena $\mathrm{a}_{\mathrm{w}}$ adalah jumlah air bebas yang dapat digunakan oleh mikroba untuk tumbuh. Menurut Vulkov (2006) nilai $\mathrm{a}_{\mathrm{w}}$ untuk pertumbuhan bakteri adalah 0,910,95; khamir 0,88; jamur 0,70 sedangkan batas minimum $\mathrm{a}_{\mathrm{w}}$ untuk dapat ditumbuhi mikroorganisme adalah 0,60.

Tabel 1 Rataan sifat fisik sampel sosis ayam dari dua kelompok pasar

\begin{tabular}{lcc}
\hline Asal Sosis ayam (Sampel) & aw & $\mathrm{pH}$ \\
\hline Swalayan & $0,91+0,01$ & $5,74+0,07$ \\
Pasar Tradisional & $0,89+0,01$ & $5,35+0,28$ \\
\hline
\end{tabular}

\section{Kualitas Mikrobiologi}

Hasil pengamatan pada sampel sosis ayam yang didapat dari dua pasar yang berbeda untuk Total Plate Count, menunjukan bahwa jumlah koloni mikrobanya masih rendah bila dibandingkan dengan SNI. Sedangkan untuk $S$. aureus, Salmonella dan E. coli masih sesuai dengan batas cemaran yang ditolerir oleh SNI. Menurut Standar Nasional Indonesia (2009) batas toleransi untuk cemaran koloni mikroba produk olahan daging berupa sosis tidak boleh lebih dari $1 \times 10^{5} \mathrm{koloni} /$ gram, Salmonella sp negatif/25 gram, E.coli <3/gram serta S.aureus $1 \times 10^{2} \mathrm{koloni} /$ gram.

Hasil analisis stastistik untuk Total Plate Count menunjukkan bahwa jumlah koloni mikroba pada sample sosis berbeda nyata $(\mathrm{P}<0,05)$ antara sampel sosis yang didapat
Tabel 2 Rataan kualitas mikrobiologi sampel sosis ayam dari dua kelompok pasar

\begin{tabular}{lcc}
\hline Bakteri & $\begin{array}{c}\text { Sosis Pasar Swalayan } \\
(\mathrm{cfu} / \mathrm{ml})\end{array}$ & $\begin{array}{c}\text { Sosis Pasar Tradis- } \\
\text { ional (cfu/ml) }\end{array}$ \\
\hline TPC & $3,67+0,41 \mathrm{a}$ & $4,82+0,74 \mathrm{~b}$ \\
Escherichia coli & $<1$ & $<1$ \\
Salmonella $\mathrm{sp}$. & $<1$ & $<1$ \\
S. aureus & $<1$ & $<1$ \\
\hline
\end{tabular}

Keterangan: Huruf yang berbeda pada baris yang sama menunjukan perbedaan yang nyata $(\mathrm{P}<0,05)$

dari swalayan (penyimpanan suhu dingin) dengan sample sosis yang didapat dari pasar tradisional (penyimpanan suhu ruang). Jumlah cemaran mikroba pada sampel sosis yang didapat dari pasar tradisional menunjukkan angka yang lebih tinggi yaitu sebesar 4,82350+0,41335 dibandingkan dengan sampel sosis yang didapat dari swalayan yaitu sebesar 3,67968 $\pm 0,41335$. Hal tersebut dapat disebabkan karena sosis yang dijual di pasar tradisional tidak disimpan pada suhu dingin sehingga pertumbuhan mikrobanya lebih banyak daripada sosis dari swalayan. Selain itu sanitasi pada pasar tradisional belum sebaik sanitasi yang dilakukan pada swalayan sehingga kemungkinan cemaran mikrobanya juga lebih tinggi.

S. aureus, Salmonella dan E. coli merupakan bakteri pathogen yang biasa digunakan sebagai indicator dari proses pengolahan makanan yang tidak higenis (Palupi et al. 2010). Ketiga bakteri pathogen di atas dapat menghasilkan toksin yang berbahaya apabila dikonsumsi oleh manusia. Namun demikian kedua sosis masih layak untuk dikonsumsi karena menurut Salasia et al. (2009) produk sosis akan mengandung toksik berbahaya bila cemaran S.aureus-nya mencapai 1 x $10^{5} \mathrm{CFU} /$ gram.

\section{Kualitas Uji Organoleptik}

Data hasil uji hedonik terhadap sosis dapat diliat pada Tabel 3. Atribut yang diujikan meliputi warna, aroma, tekstur dan rasa. Pada atribut warna, nilai modus kesukaan panelis terhadap sosis berada pada skor 4, artinya panelis menyukai warna sosis yang diujikan, baik sosis pasar tradisional maupun sosis swalayan. Pada atribut aroma, nilai modus yang diperoleh yaitu 4 pada sosis pasar tradisional, dan 5 pada sosis swalayan, artinya panelis menyukai aroma sosis pasar tradisional dan sangat menyukai aroma sosis swalayan. Pada atribut tekstur, baik sosis pasar tradisional maupun swalayan memiliki modus skor 4 yang berarti bahwa panelis menyukai tekstur sosis pasar tradisional dan swalayan. Pada atribut terakhir yaitu rasa, nilai modus kesukaan panelis terhadap sosis pasar tradisional 5, artinya panelis sangat menyukai rasa sosis pasar tradisional, sedangkan nilai modus kesukaan panelis terhadap sosis swalayan 4, artinya panelis menyukai rasa sosis swalayan.

Hasil analisis statistik menggunakan Uji KruskallWallis menunjukkan bahwa tidak ada perbedaan nyata $(\mathrm{P}>0,05)$ kesukaan panelis terhadap semua atribut yaitu warna, aroma, tekstur dan rasa, dengan kata lain perbedaan metode penyimpanan sosis pasar tradisional dan swalayan tidak berpengaruh nyata terhadap tingkat kesukaan sosis. Hal tersebut disebabkan selain proses pemasakan sosis 
Tabel 3 Modus nilai hedonik sampel sosis ayam dari dua kelompok pasar

\begin{tabular}{lcc}
\hline $\begin{array}{l}\text { Mutu } \\
\text { Hedonik }\end{array}$ & $\begin{array}{c}\text { Sosis Pasar } \\
\text { Swalayan }\end{array}$ & $\begin{array}{c}\text { Sosis Pasar } \\
\text { Tradisional }\end{array}$ \\
\hline Warna & $4 \pm 0,536$ & $4 \pm 0,678$ \\
Aroma & $5 \pm 1,107$ & $4 \pm 0,774$ \\
Tekstur & $4 \pm 0,536$ & $4 \pm 0,739$ \\
Rasa & $4 \pm 0,804$ & $5 \pm 0,734$ \\
\hline
\end{tabular}

Keterangan: Superskrip yang sama ke arah vertikal menunjukkan tidak ada perbedaan yang nyata $(\mathrm{P}>0,05)$

dilakukan bersamaan dengan lama pemasakan yang sama pula, sosis pasar maupun swalayan berasal dari merk yang sama, sehingga bahan dan alat serta proses pembuatan sudah seragam dan sesuai standar operasional pabrik. Selain itu, uji kualitas fisik dan mikrobiologi sosis pasar tradisional dan swalayan menunjukkan bahwa keduanya masih aman untuk dikonsumsi karena telah memenuhi standar dari SNI. Menurut Soeparno (2009) faktor-faktor yang mempengaruhi aroma, rasa, warna dan tekstur daging masak yaitu umur ternak, tipe pakan, spesies, jenis kelamin, lemak, bangsa, lama waktu dan kondisi penyimpanan, jenis, lama pemasakan, konsentrasi mioglobin, kondisi kimia serta fisiknya.

\section{KESIMPULAN}

Sosis ayam yang beredar di pasar sekitar kampus IPB Darmaga masih layak untuk dikonsumsi karena cemaran mikrobanya masih rendah dibandingkan dengan SNI, namun demikian cemaran mikroba pada sosis yang berasal dari pasar tradisional lebih tinggi dari pada yang berasal dari swalayan. Hasil uji organoleptic menunjukkan bahwa panelis masih dapat menerima sosis ayam dari dua kelompok pasar tersebut.

\section{Saran}

Mengkonsumsi produk olahan daging berupa sosis ayam yang berasal dari pasar yang ada disekitar kampus IPB Darmaga, sebaiknya berasal dari pasar yang menyimpan produk sosis dalam suhu dingin atau refrigerator, selain itu untuk mencegah penyakit akibat cemaran bakteri pathogen sebaiknya sosis dimasak dengan baik dan benar sampai matang.

\section{DAFTAR PUSTAKA}

AOAC. 1995. Official Methods of Analysis of The Association of Official Analytical Chemist. AOAC Int., Washington. p: 97-149.

BADAN POM (Badan Pengawas Obat dan Makanan). 2015. Grafik Kasus Keracunan Nasional yang Terjadi di Tahun 2015 Berdasarkna Kelompok Penyebab. http://ik.pom.go.id (diakses pada tanggal 11 Desember 2016).

BSN (Badan Standarisasi Nasional). 1995. Sosis Daging. Standar Nasional Indonesia 01-3820. Jakarta.

BSN (Badan Standarisasi Nasional). 2006. Petunjuk Pengujian Organoleptik dan atau Sensori. SNI 012346-2006. Jakarta: BSN.
BSN (Badan Standarisasi Nasional). 2008. Metode Pengujian Cemaran Mikroba Dalam Daging, Telur dan Susu Serta Hasil Olahannya. SNI 2897.2008. Jakarta : BSN.

BSN (Badan Standarisasi Nasional). 2009. Batas Maksimum Cemaran Mikroba Dalam Pangan. SNI 7388-2009. Jakarta: BSN.

FDA (Food and Drug Administration). 2001. Bacteriological Analytical Manual, 8th Edition, Revision A. Food and Drug Administration. Gaithersburg,USA.

KEMENKES (Kementerian Kesehatan Republik Indonesia). 2015. Pusat Data dan Informasi -Situasi Pangan Jajanan Anak Sekolah. Jakarta Selasan.

Kramlich, W.E. 1973. Sausage Product, $2^{\text {nd }}$ edition. San Fransisco: W H Freeman Company.

Matjik, A.A., M. I. Sumertajaya. 2013. Perancangan percobaan dengan aplikasi SAS dan Minitab. Cetakan keempat: April 2013, Bogor: IPB Press. Hlm 47-51.

Meilgaard, M., G.V. Civille \& B.T. Carr. 1999. Sensory Evaluation Techniques New York: CRC Press.

Muttaqien, A. T., A. M. P. Nuhriawangsa, Pudjomartatmo dan W. Swastike. 2013. Sifat Fisik Edible Film dari Gelatin Shank Ayam Broiler dan Pengaruh Penggunaannya terhadap emaran Mikroba Sosis Daging Sapi dengan Masa Simpan yang Berbeda. Journal Tropical Animal Husbandry. 2 (1) :15-20.

Palupi, K.T., Adiningsih, MW, Sunartatie, T, Afiff, U, Purnawarman, T. 2010. Pengujian Staphylococcus aureus pada Daging Ayam Beku yang Dilalulintaskan Melalui Pelabuhan Penyeberangan Merak. Majalah Kehewanan Indonesia.1(2): 1-12.

Salasia, S., Khusnan, Sugiyono. 2009. Distribusi Gen Enterotoksin Staphylococcus aureus dari Susu Segar dan Pangan Asal Hewan. J.Vet.10: 111-117.

Steel, R.G.D dan J.H. Torrie. 1993. Prinsip dan Prosedur Statistika. Terjemahan Bambang Sumantri. Gramedia. Jakarta.

Suparno. 2009. Ilmu dan Teknologi Daging. Yogyakarta: Gadjah Mada University Press.

Vulkov, P. 2006. Water activity concept for safety food storage. Journal Proceedings of the rd Central European Congress on Food:1-8. 